\title{
Determining the risk of predator attacks around protected areas: the case of Bardia National Park, Nepal
}

\author{
Subodh K. Upadhy ya, C.J.M. Musters \\ Babu Ram Lamichiane, Geert R. De Snoo \\ MaheshWAR DhaKal and Hans H. De IONGH
}

\begin{abstract}
In this study we determined the probability of predator attacks on livestock around Bardia National Park, Nepal. We conducted semi-structured interviews to explore the patterns and factors affecting livestock losses in four administrative sectors of the Park's buffer zone. We developed models to investigate the overall probability of livestock loss, economic damage caused, and the respondents' attitudes towards wildlife. The probability of leopard attacks on livestock was much higher $(85 \%$ of all livestock lost to depredation) than that of tiger attacks (8\%), and the northern sector experienced the highest loss of livestock (50\% modelled probability of livestock loss) in the buffer zone. Livestock loss was significantly related to the number of livestock owned by respondents, their ethnic group, and village distance to the Park boundary. Economic damage was influenced by buffer zone sector, number of livestock owned, and distance to the Park boundary. Conservation attitudes depended on respondents' knowledge of wildlife, levels of education and self-sufficiency, and the probability of livestock being killed by leopards. Respondents who were male, highly educated and self-sufficient were most likely to support conservation. Tigers are tolerated based on religious beliefs, and these cultural values, together with the sharing of conservation benefits, facilitate conservation. Leopards, however, are not tolerated in the same way and are the most damaging predators.
\end{abstract}

Subodh K. UpadhyayA* (Corresponding author, (D) orcid.org/0000-0003-40189285), C.J.M. Musters, Geert R. De Snoo and Hans H. DE Iongh $\ddagger$ Institute of Environmental Sciences (CML), Leiden University, Einsteinweg 2, 2333 CC, Leiden, The Netherlands. E-mail subodh@ku.edu.np

Babu Ram Lamichnane†t (D orcid.org/0000-0003-0580-7682) National Trust for Nature Conservation, Biodiversity Conservation Center, Sauraha, Chitwan, Nepal

Maheshwar Dhakal Ministry of Forest and Soil Conservation, Biodiversity and Environment Division, Singhadurbar, Kathmandu, Nepal

${ }^{*}$ Also at: School of Science, Kathmandu University, Dhulikhel, Kavre, Kathmandu, Nepal

$\dagger$ Also at: Institute of Cultural Anthropology and Development Sociology, Leiden University, Leiden, The Netherlands

¥Also at: Evolutionary Ecology Group, Faculty of Sciences, Antwerp University, Antwerp, Belgium

Received 12 June 2018. Revision requested 9 August 2018.

Accepted 13 November 2018. First published online 2 July 2019.
Keywords Attitudes, economic loss, human-wildlife conflict, leopard, livestock depredation, Nepal, risk modelling, tiger

Supplementary material for this article is available at https://doi.org/10.1017/So030605318001436

\section{Introduction}

T arge carnivore populations have declined globally for a $\checkmark$ variety of reasons, but mostly because of human interventions (Woodroffe \& Ginsberg, 1998; Karanth \& Chellam, 2009). Poaching for traditional medicine and furs, habitat destruction and depletion of their natural prey are major threats (Smith et al., 1998; Treves \& Karanth, 2003). Trophy hunting and retaliatory killing in response to livestock depredation have also had adverse effects on lion populations in Africa (Bauer \& Iongh, 2005; Croes et al., 2011).

Several studies have reported raised levels of so-called human-wildlife conflict (Madden, 2004) in areas where large carnivore populations have started to increase as a result of conservation actions (Saberwal et al., 1994; Treves \& Karanth, 2003; Inskip \& Zimmermann, 2009; Seidensticker, 2010; Silwal et al., 2017). However, the use of the term human-wildlife conflict is misleading because, in reality, the conflict is often between conservation and other human interests (Peterson et al., 2010; Redpath et al., 2015; Fisher, 2016).

Predator attacks on livestock are one of the most serious challenges faced by villagers in and near protected areas, with tigers Panthera tigris and leopards Panthera pardus killing 118 and 123 livestock annually in Bardia and Chitwan National Parks, respectively (Lamichhane et al., 2018). Despite these losses, people living around protected areas in Asia are relatively tolerant of wildlife (Dinerstein et al., 2007; Karanth \& Nepal, 2012) compared to Indigenous People of other regions because their cultural values and beliefs promote wildlife conservation (Gogoi et al., 2018). Because the recovery of both leopard and tiger populations depends on the capacity of local communities to coexist with them, conflict mitigation measures need to be implemented in areas where these felids occur 
in the vicinity of human settlements (Treves et al., 2006; Woodroffe et al., 2007; Carter et al., 2012).

Here we aim to (1) identify the probability of livestock loss to predator attacks and other factors, such as disease and flooding, in different sectors of the buffer zone of Bardia National Park; (2) quantify the economic damage to resident communities caused by predator attacks; and (3) assess the residents' attitudes towards the conservation of tigers, leopards and other wildlife, and the factors underlying these attitudes.

\section{Study area}

Bardia National Park (henceforth Bardia, IUCN category II), established in 1976, is located in south-western Nepal (Fig. 1). It is the largest national park in the plains (terai) of Nepal (968 $\mathrm{km}^{2}$; DNPWC, 2018) and one of the prime habitats for tigers and leopards in the country (Walston et al., 2010). The Park's $327 \mathrm{~km}^{2}$ buffer zone was established in 1996 , with an additional $180 \mathrm{~km}^{2}$ of primarily hilly terrain in the Surkhet district included in 2010. According to regulations $30-50 \%$ of the revenue generated by the protected area are to be invested in the buffer zone, to minimize the impact of wildlife on local communities (Baral \& Heinen, 2007).
The rapid expansion of human settlements, habitat degradation, and poaching caused tiger numbers to fall to 18 individuals inside the Park in 2009. However, the tiger population had increased to 50 individuals in 2013 (Dhakal et al., 2014). Leopard numbers have not been assessed recently in Bardia, but Wegge et al. (2009) estimated their density to be 5 individuals $/ 100 \mathrm{~km}^{2}$.

The Park has three distinct seasons: winter (late September-mid February), summer (mid February-mid June) and monsoon (mid June-September). The maximum temperature is $45^{\circ} \mathrm{C}$ and mean annual rainfall is $1,500 \mathrm{~mm}$ (Dinerstein, 1979; DNPWC, 2018). Flooding in 2014 caused significant loss of human life and livestock (Bhattarai et al., 2016), but loss of wildlife was not documented.

Indigenous Tharu people and migrants from the hills (Pahade) inhabit the buffer zone of the Park (Bhattarai et al., 2016). The majority of households are involved in subsistence farming supplemented by livestock grazing in forests and grassland (Thapa Karki, 2013). Rice and maize are grown mainly in the monsoon, whereas wheat, mustard and lentils are grown in winter, for domestic consumption (Studsrød \& Wegge, 1995). Livestock including cattle, buffalo, sheep, goats, pigs and chickens are kept by villagers primarily for milk, meat, manure and draught power (Thapa Karki, 2013).

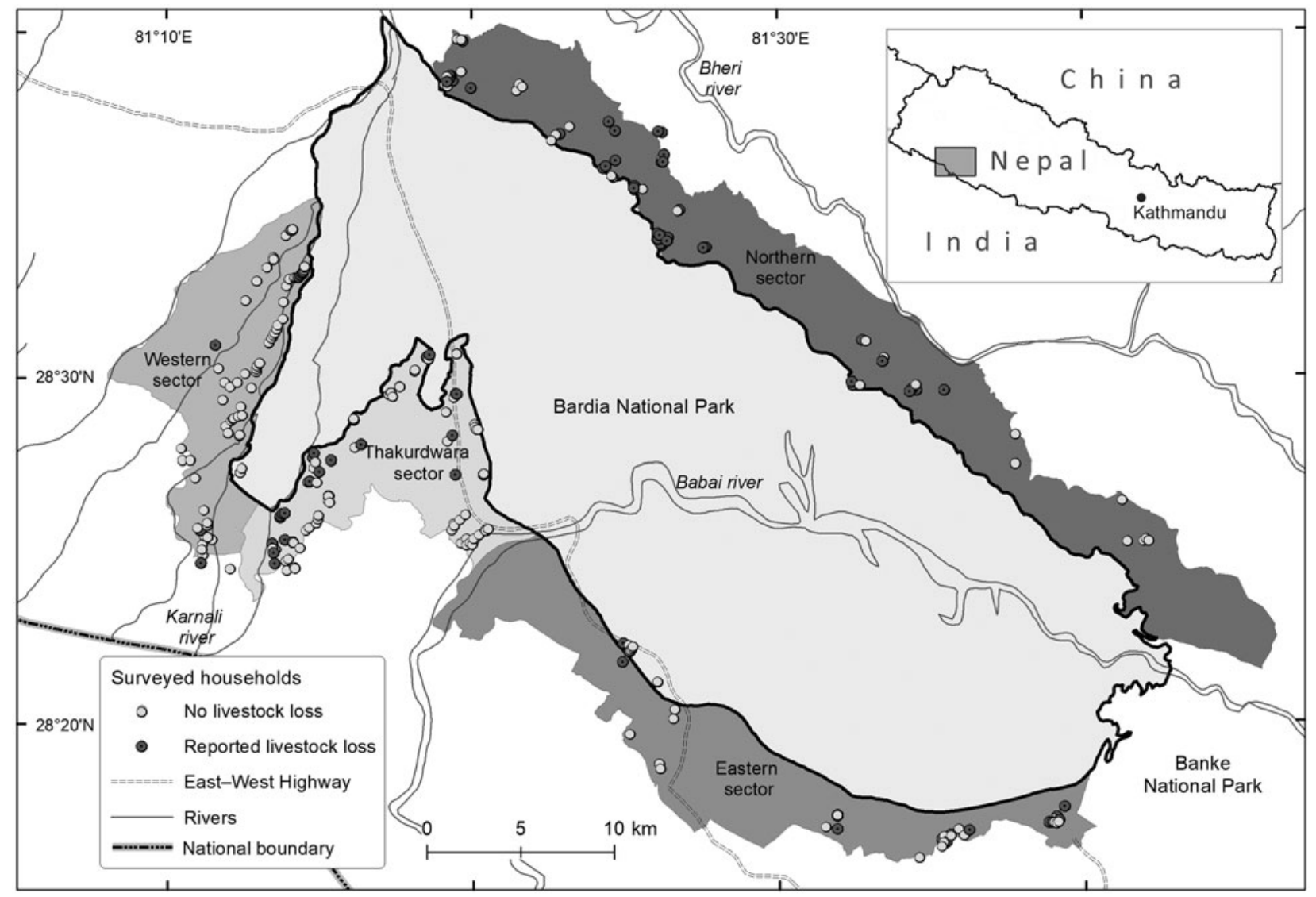

FIG. 1 Bardia National Park and its buffer zone, showing the study sectors, surveyed households and cases of reported livestock loss. 


\section{Methods}

\section{Data collection}

We used a semi-structured questionnaire survey (Supplementary Material 1; adapted from Sogbohossou et al., 2011 and Bhattarai \& Fischer, 2014) of 297 households that were opportunistically selected in the four study sectors, taking into account the size and the total number of households in each sector (Table 1). Interviews with the heads of the selected households took place during May-August 2015 and were conducted in Nepali by native Nepali and Tharu language speakers who also worked as tourist guides in Bardia. They were trained and instructed on the structure and purpose of the questionnaire before the interview, and during the course of the survey regular assessments were performed to limit any bias that could have resulted from their positive attitude towards conservation as professional nature guides.

We divided the surveyed communities into four groups based on their location in Park management sectors. We considered relative densities of livestock and natural prey in these sectors to be important factors contributing to the probability of predator attacks. The Thakurdwara and western sectors were characterized by relatively high densities of both natural prey and livestock, whereas the eastern and northern sectors had relatively low densities of natural prey but high livestock densities.

\section{Data analyses and statistics}

We developed logistic models to estimate (1) overall probability of loss of livestock and poultry (including loss caused by predator attacks and other factors such as disease or natural calamities), (2) probability of loss to all predators combined, and (3) probability of loss to leopards in particular. We used a linear model for economic loss (i.e. the cost of livestock losses to predator attacks and other factors).

We further created logistic models for attitude (which was either positive, coded as 1, or negative, coded as o) towards (1) wildlife in general, (2) wildlife conservation in general, (3) wildlife conservation when family members were affected by wildlife, and (4) wildlife conservation amongst respondents personally affected by livestock losses to predators. All models were created in $R$ (R Core Team, 2018). We used a likelihood ratio test to compare models with and without independent variables (Bolker et al., 2009; see Supplementary Table 1 for all variables).

\section{Results}

Respondents, 254 men and 43 women, were 16-76 years old (mean 40 years). The majority $(87 \%)$ were literate.
TABLE 1 The number of households interviewed per sector in Bardia National Park, Nepal.

\begin{tabular}{lcc}
\hline Sector & $\begin{array}{l}\text { No. of households } \\
\text { in sector }\end{array}$ & $\begin{array}{l}\text { No. of households } \\
\text { interviewed }\end{array}$ \\
\hline Thakurdwara & 5,265 & 87 \\
Eastern & 4,414 & 53 \\
Western & 5,099 & 80 \\
Northern & 1,856 & 77 \\
Total & 16,634 & 297 \\
\hline
\end{tabular}

Twenty-four per cent had completed a basic education, $18 \%$ were educated to primary, $23 \%$ to lower secondary and $14 \%$ to secondary level, and $8 \%$ had completed a higher secondary or university level education. Just over half of respondents $(52 \%)$ were able to sustain their households on their own production for 9-12 months, whereas for $48 \%$ this period was $<9$ months. Interviewees were of several cultural backgrounds, with $46 \%$ Tharus, $37 \%$ Brahmin or Chhetri, $11 \%$ Dalits and 6\% from other ethnic groups. Most (c. 85\%) respondents were farmers. The mean household size was 5 persons and the mean numbers of livestock kept by respondents were 1.56 cattle, 4.49 sheep/goats, 0.95 buffalo and 0.58 pigs. The northern sector contained $43 \%$ of total livestock in the buffer zone, Thakurdwara sector $23 \%$, and western and eastern sectors 21 and $13 \%$, respectively.

Over half (c. 59\%) of respondent households were within $2 \mathrm{~km}$ of the Park boundary, $36 \% 3-4 \mathrm{~km}$, and $4 \%>5 \mathrm{~km}$ from the Park boundary. In total, 131 (44\%) household heads reported loss of livestock and poultry either to predator attacks (92 cases, $70 \%$ ) or other factors such as disease and flooding (39 cases, 30\%). Of the 92 cases of livestock and poultry depredation, 78 (85\%) were caused by leopards, eight (8\%) by tigers, and six ( $7 \%$ ) by other wildlife (foxes Vulpes vulpes, jackals Canis aureus, crocodiles Crocodylus palustris, pythons Python bivittatus and eagles Aquila spp.). Leopards killed primarily goats ( $68 \%$ of leopard attacks), followed by pigs (14\%), sheep (12\%) and cattle (6\%). Tigers killed seven cattle $(87.5 \%$ of tiger attacks) and one buffalo (12.5\%). Crocodiles and foxes killed goats, whereas other wildlife killed poultry only. Predator attacks were more common in summer (46\%) and winter (35\%) than in the monsoon (19\%). The majority ( $81 \%)$ of losses occurred inside the village and $19 \%$ outside a settlement, in the forest. Most respondents (c. 90\%) were able to distinguish a tiger from a leopard based on photographs. They were also able to recognize the predators based on pugmarks at the kill site and bite marks on the livestock carcass, which was confirmed by the Park authority when verifying compensation claims.

\section{Probability of loss}

The probabilities of livestock loss per household for each study sector, with their respective causes, are shown in 
TABLE 2 Probabilities of livestock loss per household in each study sector caused by tigers Panthera tigris, leopards Panthera pardus and other factors.

\begin{tabular}{llllll}
\hline \multicolumn{5}{c}{ Loss caused by } \\
\cline { 2 - 6 } & \multicolumn{5}{c}{$\begin{array}{l}\text { Large felids } \\
\text { (tigers \& }\end{array}$} \\
Sector & Wildlife & leopards) & Tigers & Leopards & factors \\
\hline Thakurdwara & 0.30 & 0.24 & 0.02 & 0.22 & 0.43 \\
Eastern & 0.38 & 0.38 & 0.02 & 0.36 & 0.43 \\
Western & 0.10 & 0.09 & 0.06 & 0.03 & 0.35 \\
Northern & 0.55 & 0.53 & 0.01 & 0.52 & 0.69 \\
All sectors & 0.32 & 0.30 & 0.03 & 0.27 & 0.47 \\
\hline
\end{tabular}

Table 2. The overall probability of livestock loss was positively related to livestock grazing in the community forest $(\mathrm{P}=0.004)$, ethnic group $(\mathrm{P}=0.04)$, the number of pigs owned by the respondent $(\mathrm{P}=0.02)$ and study sector $(\mathrm{P}=0.02)$. Leopard attacks on livestock showed a strong relationship with study sector $(\mathrm{P}<0.001$; Supplementary Table 2). Livestock grazing in the government forest $(\mathrm{P}=0.04)$, ethnic group $(\mathrm{P}=0.04)$, number of goats and sheep owned $(\mathrm{P}=0.02)$ and number of pigs owned $(\mathrm{P}=0.01)$ were significantly related to study sector (Supplementary Table 2).

In all three models, the probability of livestock loss was highest in the northern sector (c. 50\%), followed by the eastern (c. 30\%) and the Thakurdwara (c. 20\%) sectors (Fig. 2a), and the probability of loss in the Tharu ethnic group was lower than for other ethnic groups (Fig. 2b). Approximately $79 \%$ of predator attacks took place when livestock was held inside corals and $52 \%$ occurred at night.

\section{Economic loss}

The total costs of livestock lost to predator attacks and other factors was USD 22,927 for the surveyed households, of which USD $14,573(63.5 \%)$ was a result of predatory attacks and USD 8,353 (36.5\%) because of other factors (Table 3). The mean value of livestock species ranged from USD 30 to USD 50 per animal, depending on their size. The linear model suggests that the most important factors contributing to the predation-related economic loss were study sector $(\mathrm{P}<0.001)$ and distance to the National Park $(\mathrm{P}=0.003$; Table 4).

\section{Attitudes towards wildlife}

Of the 270 responses on questions exploring attitudes towards wildlife, $85 \%$ were positive. Most (93\%) respondents were supportive of wildlife conservation in general, even when family members had suffered wildlife-related losses. Approximately $80 \%$ of the respondents who had personally suffered livestock losses from predator attacks in the past indicated they still support the protection and conservation of wildlife (Table 5).

Our logistic model on attitudes towards wildlife showed that respondents from the western sector were most supportive of conservation, followed by Thakurdwara, eastern, and northern sectors, in this order $(\mathrm{P}=0.03)$. Respondents with a higher level of education were more positive towards wildlife in general $(\mathrm{P}=0.004)$ and willing to conserve wildlife $(\mathrm{P}=0.02)$. Respondents who were self-sufficient (i.e. generating crop yields that could sustain their household throughout the year) were more positive about wildlife conservation in general than respondents who were not selfsufficient $(\mathrm{P}=0.03)$. Men were more positive about wildlife conservation than women $(\mathrm{P}=0.10$; Supplementary Table 3). Contrary to our expectations, respondents who had lost livestock to tigers had a positive attitude towards wildlife conservation $(\mathrm{P}=0.06)$.

The model on attitudes towards wildlife conservation shows that self-sufficiency and education level were positively related to a positive attitude $(\mathrm{P}=0.01$ and 0.02$)$, even when family members had lost livestock to predators. There is an indication that the overall probability of loss affects attitudes towards conservation $(\mathrm{P}=0.06$; Supplementary Table 3$)$.

The attitude of respondents who had personally suffered livestock losses varied between study sectors. The majority (c. 98\%) of respondents in the Thakurdwara and western sectors, $80 \%$ in the eastern and only $50 \%$ in the northern sector were positive towards wildlife conservation after
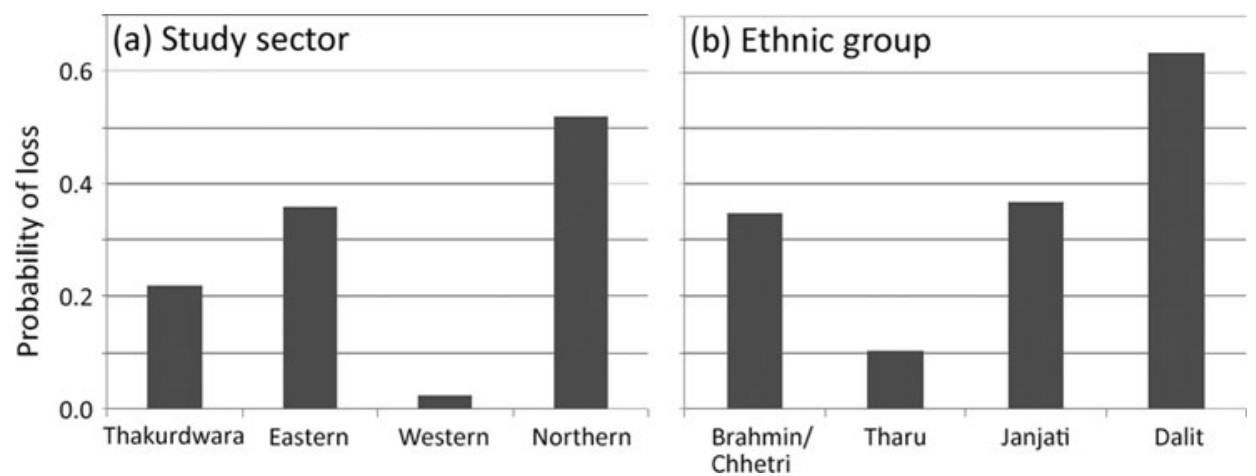

FIG. 2 Probability of livestock loss to leopards by (a) study sector and (b) ethnic group. 
TABLE 3 Cost (in USD) of overall livestock loss, loss to predators and loss caused by other factors in each study sector. Mean cost per affected household is given in parentheses.

\begin{tabular}{lccc}
\hline Sector & $\begin{array}{l}\text { All livestock } \\
\text { loss }\end{array}$ & $\begin{array}{l}\text { Loss caused } \\
\text { by predators }\end{array}$ & $\begin{array}{l}\text { Loss caused } \\
\text { by other factors }\end{array}$ \\
\hline Thakurdwara & $2,995(34)$ & $2,507(29)$ & $488(6)$ \\
Eastern & $2,067(39)$ & $1,676(32)$ & $391(7)$ \\
Western & $7,446(93)$ & $2,181(27)$ & $5,265(66)$ \\
Northern & $10,419(135)$ & $8,210(107)$ & $2,209(29)$ \\
Total & $22,927(75)$ & $14,574(49)$ & $8,353(27)$ \\
\hline
\end{tabular}

TABLE 4 Linear model for economic loss caused by predators, with results of the likelihood ratio test: degrees of freedom, deviance of the model without the tested variable, Akaike information criterion (AIC) of the model without the tested variable, difference between the deviance of the complete model and that of the model without the tested variable $\left(\chi^{2}\right)$, and P-value.

\begin{tabular}{|c|c|c|c|c|c|}
\hline Variables & Df & Deviance & AIC & $\chi^{2}$ & $\mathrm{P}$-value \\
\hline Sector & 3 & 139.39 & 407.43 & 19.8562 & $0.0001818^{\star * *}$ \\
\hline No. of cattle & 1 & 124.96 & 396.68 & 5.1021 & $0.0238966^{\star}$ \\
\hline $\begin{array}{l}\text { No. of goats \& } \\
\text { sheep }\end{array}$ & 1 & 124.96 & 396.68 & 5.1066 & $0.0238355^{\star}$ \\
\hline No. of buffalo & 1 & 120.54 & 391.82 & 0.2473 & 0.6189475 \\
\hline No. of pigs & 1 & 121.44 & 392.82 & 1.2455 & 0.2644177 \\
\hline No. of poultry & 1 & 122.88 & 394.41 & 2.8374 & 0.0920938 \\
\hline $\begin{array}{l}\text { Loss caused } \\
\text { by predators }\end{array}$ & 1 & 122.92 & 394.46 & 2.8805 & 0.0896566 \\
\hline $\begin{array}{l}\text { Loss caused by } \\
\text { other factors }\end{array}$ & 1 & 122.52 & 394.02 & 2.4443 & 0.1179525 \\
\hline $\begin{array}{l}\text { Distance to } \\
\quad \text { National Park }\end{array}$ & 1 & 128.52 & 400.47 & 8.8931 & $0.0028624^{* *}$ \\
\hline
\end{tabular}

${ }^{*} \mathrm{P}<0.05$

${ }^{*} \mathrm{P}<0.01$

${ }^{* * *} \mathrm{P}<0.001$

having lost livestock to predators (Table 5). The proportion of positive responses increased with educational level (illiterate, 60\%; primary level education, $80 \%$; $\mathrm{P}<0.001$ ). The overall probability of livestock loss also affected attitudes, with a lower probability of livestock loss being linked to a more positive attitude $(\mathrm{P}=0.03)$.

\section{Discussion}

Household surveys provide insight into how people live and interact with wildlife. We found that leopards caused the majority of livestock loss around Bardia National Park, in contrast to Acharya et al. (2016) who reported that leopards contributed to $21 \%$ of livestock depredation in Nepal. Signs of leopards were found primarily near the edge of the Park in Bardia (Studsrød \& Wegge, 1995; Tamang \& Baral, 2008; Upadhyaya et al., 2018), which has also been reported in
Nepal's Chitwan National Park (Bhattarai \& Kindlmann, 2012) and Macharia National Park, Pakistan (Dar et al., 2009). Livestock loss was related to the number of livestock held in the area, which is similar to findings of Tamang \& Baral (2008) from Bardia, Oli et al. (1994) from the Annapurna conservation area in Nepal, and Wang \& Macdonald (2006) from Bhutan. Livestock depredation was higher inside corrals than in the forest, as reported by Tamang \& Baral (2008).

Tharu people reported minimal losses, although they owned similar numbers of cattle to people of other ethnic groups. This could be related to the Tharu's long experience of living with wildlife as an Indigenous group and their better livestock husbandry practices, such as more effective enclosures (Kolipaka et al., 2017). Distance to Park boundary is an important determinant of predator attacks on livestock: attack probability increased at distances below $5-12 \mathrm{~km}$ in Bardia and in Waza National Park, Cameroon (Studsrød \& Wegge, 1995; Van Bommel et al., 2007).

Households in the northern sector suffered considerably higher economic damage compared to other sectors, which can be attributed to poor husbandry techniques, such as open sheds. Villagers with a lower socio-economic status lost significantly more livestock compared to villagers who could afford better protection measures and husbandry techniques such as predator-proof corrals (Saberwal et al., 1994). People from marginalized groups are severely affected by such financial losses (Manral et al., 2016).

Economic loss caused by predator attacks in the study area was comparable to losses resulting from other causes, specifically two adverse natural events: a flood in 2014, which caused a rise in livestock deaths, and a bird-flu outbreak in July 2015, which led to high losses of poultry. In other areas, studies have shown that even where livestock predation is considered to be a major cause of economic loss, other factors such as disease and theft actually contributed more to overall economic losses than predator attacks (Dar et al., 2009; Tumenta et al., 2013).

The difference in attitudes between respondents from the western sector ( $98 \%$ had a positive attitude towards wildlife conservation) and those from the northern sector (c. $70 \%$ were positive), is probably a consequence of the difference in numbers of livestock lost between these two sectors. In addition, interviewees from the northern sector were generally dissatisfied because this area was incorporated into the Park's buffer zone more recently (in 2010) and residents have not benefitted from the buffer zone programme to the same extent as people in other sectors, where $30-50 \%$ of Park revenue has been allocated to community development activities. Although people's attitudes towards wildlife can be influenced by predator attacks and other wildlife-related financial losses (Røskaft et al., 2007), in general people are more tolerant of wildlife if they derive benefits from a protected area (Allendorf et al., 2007; Baral \& 
TABLE 5 Attitudes towards wildlife in general and willingness to support conservation, depending on the respondents' experience with livestock depredation, in per cent of respondents in each study sector.

\begin{tabular}{lllll}
\hline & & \multicolumn{2}{l}{ Willingness to support conservation } \\
\cline { 3 - 5 } Sector & $\begin{array}{l}\text { Positive attitude } \\
\text { towards wildlife }\end{array}$ & All respondents & $\begin{array}{l}\text { Respondents with family } \\
\text { affected by depredation }\end{array}$ & $\begin{array}{l}\text { Respondents personally } \\
\text { affected by depredation }\end{array}$ \\
\hline Thakurdwara & 90 & 95 & 97 & 97 \\
Eastern & 73 & 93 & 87 & 76 \\
Western & 99 & 99 & 96 & 96 \\
Northern & 73 & 84 & 88 & 46 \\
All sectors & 85 & 93 & 93 & 80 \\
\hline
\end{tabular}

Heinen, 2007; Romañach et al., 2007; Pant et al., 2016; Wegge et al., 2018). Therefore, active involvement of local communities in planning, executing and managing smallscale conservation projects leads to a positive attitude towards conservation (Nepal, 2002).

Despite the differences between the study sectors, c. $65 \%$ and c. $80 \%$ of all respondents had a positive attitude towards conservation even when leopards or tigers, respectively, had killed their livestock. The fact that tigers were regarded more favourably is a reflection of the cultural values prevalent in this region (Bhattarai \& Fischer, 2014; Kolipaka et al., 2015): people from Bardia believe that tigers are the vehicle of Durga, the goddess of might, and should not be harmed (Bhattarai \& Fischer, 2014), whereas leopards do not benefit from tolerance based on religious beliefs.

Respondents educated to a higher level and with a greater degree of self-sufficiency had a more positive attitude towards conservation, which confirms findings of other studies (Allendorf et al., 2006; Sarker \& Røskaft, 2011; Sogbohossou et al., 2011; Tumenta et al., 2013; Bhattarai \& Fischer, 2014). In Bangladesh, wealthy respondents favoured wildlife conservation 7.4 times more than their less wealthy peers (Sarker \& Røskaft, 2011). People relying on a single source of income or few resources are more vulnerable to the impact of depredation (Ogra, 2008; Dickman, 2010). More educated people are generally less dependent on natural resources for their sustenance than their less educated neighbours (Dickman, 2010). Education can therefore be an important tool in wildlife conservation at the local scale (Nepal \& Weber, 1995), and conservation authorities could also promote existing Indigenous knowledge and technologies to reduce negative human-wildlife interactions (Kolipaka et al., 2017). Women had a less positive attitude towards conservation than men, which may be linked to the risks they are exposed to when collecting forest products, making them more vulnerable, and as a result, more vigilant, in the vicinity of wildlife (Allendorf, 2010; Bhattarai \& Fischer, 2014). However, we cannot generalize this because of the low number of women amongst the respondents in our study. Similar to our results, Carter et al. (2014) reported that women, less educated persons and people from marginalized groups have negative attitudes, specifically towards tigers.

We expect that our findings will be of value to Bardia wildlife managers and other conservation authorities in the region, to help predict where predation by tigers and leopards is most likely to occur, and design intervention strategies that can reduce financial losses caused by predators (Kansky \& Knight, 2014). When planning mitigation measures in and around Bardia, managers should consider the specific behavioural traits of the felid species involved, such as taking cover in dense vegetation and attacking in dark. To reduce the impact of livestock depredation we recommend (1) improvement in enclosure and herding practices, (2) reduction in the number of livestock by diversifying the economy, (3) implementation of a community-based livestock insurance programme, and (4) establishment of an early warning system such as deployment of motion sensors around corrals and mobile alerts.

Acknowledgements We thank the Department of National Parks and Wildlife Conservation, Kathmandu, Nepal for permission to conduct the research. Financial support was provided by Nuffic NFP (Netherlands Organization for International Cooperation in Higher Education, Netherlands Fellowship Programme). We thank Ram Chandra Kandel, Ramesh Thapa and Ashok Bhandari for their support and permission to work in Bardia; Rabin Kadariya, Ambika Prasad Khatiwada, Shree Ram Ghimire and Shailendra Yadav from the National Trust for Nature Conservation, Bardia for providing logistical support; the communities residing in the buffer zone for their participation; Hemanta Acharya and his team for conducting interviews; two anonymous reviewers for their critiques; and Barbara Croes for language editing.

Author contributions Conception and study design: all authors; data collection: SKU; statistical models and data analyses: CJM and SKU; writing and revisions: all authors.

\section{Conflict of interest None.}

Ethical standards This research complies with the Oryx ethical guidelines. The interview questionnaire was reviewed and approved by the Institute of Environmental Science, Leiden University, and we obtained verbal consent from each respondent before starting the interview. 


\section{References}

Acharya, K.P., Paudel, P.K., Neupane, P.R. \& Köhl, M. (2016) Human-wildlife conflicts in Nepal: patterns of human fatalities and injuries caused by large mammals. PLOS ONE, 11, e0161717.

Allendorf, T.D. (2010) A framework for the park-people relationship: insights from protected areas in Nepal and Myanmar. International Journal of Sustainable Development and World Ecology, 17, 417-422.

Allendorf, T.D., Swe, K.K., Oo, T., Htut, Y., Aung, M., Aung, M. et al. (2006) Community attitudes toward three protected areas in Upper Myanmar (Burma). Environmental Conservation, 33, 344-352.

Allendorf, T.D., Smith, J.L.D. \& Anderson, D.H. (2007) Residents' perceptions of Royal Bardia National Park, Nepal. Landscape and Urban Planning, 82, 33-40.

Baral, N. \& Heinen, J.T. (2007) Resources use, conservation attitudes, management intervention and park-people relations in the western terai landscape of Nepal. Environmental Conservation, $34,64-72$.

Bauer, H. \& Iongh, H.H. (2005) Lion (Panthera leo) home ranges and livestock conflicts in Waza National Park, Cameroon. African Journal of Ecology, 43, 208-214.

Bhattarai, B.R. \& Fischer, K. (2014) Human-tiger Panthera tigris conflict and its perception in Bardia National Park, Nepal. Oryx, 48, 522-528.

Bhattarai, B.P. \& Kindlmann, P. (2012) Interactions between Bengal tiger (Panthera tigris) and leopard (Panthera pardus): implications for their conservation. Biodiversity and Conservation, 21, 2075-2094.

Bhattarai, B.R., Wright, W. \& Khatimada, A. (2016) Illegal hunting of prey species in the northern section of Bardia National Park, Nepal: implications for carnivore conservation. Environments, 3, 32 .

Bolker, B.M., Brooks, M.E., Clark, C.J., Geange, S.W., Poulsen, J.R., Stevens, M.H.H. \& White, J.S.S. (2009) Generalized linear mixed models: a practical guide for ecology and evolution. Trends in Ecology and Evolution, 24, 127-135.

Carter, N.H., Shrestha, B.K., Karki, J.B., Pradhan, N.M.B. \& LIU, J. (2012) Coexistence between wildlife and humans at fine spatial scales. Proceedings of the National Academy of Sciences of the United States of America, 109, 15360-15365.

Carter, N.H., Riley, S.J., Shortridge, A., Shrestha, B.K. \& Liu, J. (2014) Spatial assessment of attitudes toward tigers in Nepal. Ambio, 43, 125-137.

Croes, B.M., Funston, P.J., Rasmussen, G., Buij, R., Saleh, A., Tumenta, P.N. \& De Iongh, H.H. (2011) The impact of trophy hunting on lions (Panthera leo) and other large carnivores in the Bénoué Complex, northern Cameroon. Biological Conservation, 144, 3064-3072.

Dar, N.I., Minhas, R.A., Zaman, Q. \& Linkie, M. (2009) Predicting the patterns, perceptions, and causes of human-carnivore conflict in and around Machiara National Park, Pakistan. Biological Conservation, 142, 2076-2082.

Dhakal, M., Karki, M., Jnawali, S.R., Subedi, N., Pradhan, N.M.B., Malla, S. et al. (2014) Status of Tigers and Prey in Nepal. Department of National Park and Wildlife Conservation, Kathmandu, Nepal

Dickman, A.J. (2010) Complexities of conflict: the importance of considering social factors for effectively resolving human-wildlife conflict. Animal Conservation, 13, 458-466.

Dinerstein, E. (1979) An ecological survey of the Royal Karnali Bardia Wildlife Reserve, Nepal. Part II: habitat and animal interactions. Biological Conservation, 16, 265-300.
Dinerstein, E., Loucks, C., Wikramanayake, E., Ginsberg, J., Sanderson, E., Seidensticker, J. et al. (2007) The fate of wild tigers. BioScience, 57, 508-514.

DNPWC (Department of National Parks and Wildlife Conservation) (2018) Http://www.dnpwc.gov.np/ [accessed 13 August 2018].

Fisher, M. (2016) Whose conflict is it anyway? Mobilizing research to save lives. Oryx, 50, 377-378.

Gogol, M. (2018) Emotional coping among communities affected by wildlife-caused damage in north-east India: opportunities for building tolerance and improving conservation outcomes. Oryx, 52, 214-219.

Inskip, C. \& Zimmermann, A. (2009) Human-felid conflict: a review of patterns and priorities worldwide. Oryx, 43, 18-34.

KansKy, R. \& KNight, A.T. (2014) Key factors driving attitudes towards large mammals in conflict with humans. Biological Conservation, 179, 93-105.

Karanth, K.U. \& Chellam, R. (2009) Carnivore conservation at the crossroads. Oryx, 43, 1-2.

Karanth, K.K. \& Nepal, S.K. (2012) Local residents perception of benefits and losses from protected areas in India and Nepal. Environmental Management, 49, 372-386.

Kolipaka, S.S., Persoon, G.A., De Iongh, H.H. \& Srivastava, D.P. (2015) The influence of people's practices and beliefs on conservation: a case study on human-carnivore relationships from the multiple use buffer zone of the Panna Tiger Reserve, India. Journal of Human Ecology, 52, 192-207.

Kolipaka, S.S., Tamis, W.L.M., Van't Zelfde, M., Persoon, G.A. \& DE IONGH, H.H. (2017) Wild versus domestic prey in the diet of reintroduced tigers (Panthera tigris) in the livestock-dominated multiple-use forests of Panna Tiger Reserve, India. PLOS ONE, 12, e0174844.

Lamichhane, B.R., Persoon, G.A., Leirs, H., Poudel, S., Subedi, N., Pokheral, C.P. et al. (2018) Spatio-temporal patterns of attacks on human and economic losses from wildlife in Chitwan National Park, Nepal. PLOS ONE, 13, e0195373.

MAdDen, F. (2004) Creating coexistence between humans and wildlife: global perspectives on local efforts to address humanwildlife conflict. Human Dimensions of Wildlife, 9, 247-257.

Manral, U., Sengupta, S., Hussain, S.A., Rana, S. \& Badola, R. (2016) Human wildlife conflict in India: a review of economical implication of loss and preventive measures. Indian Forester, 142, 928-940.

NEPAL, S.K. (2002) Linking parks and people: Nepal's experience in resolving conflicts in parks and protected areas. International Journal of Sustainable Development and World Ecology, 9, 75-90.

Nepal, S.K. \& Weber, K.E. (1995) Managing resources and resolving conflicts: National parks and local people. International Journal of Sustainable Development and World Ecology, 2, 11-25.

OGRA, M.V. (2008) Human-wildlife conflict and gender in protected area borderlands: a case study of costs, perceptions, and vulnerabilities from Uttarakhand (Uttaranchal), India. Geoforum: Journal of Physical, Human, and Regional Geosciences, 39, 1408-1422.

Oli, M.K., Taylor, I.R. \& Rogers, M.E. (1994) Snow leopard Panthera uncia predation of livestock - an assessment of local perceptions in the Annapurna conservation area, Nepal. Biological Conservation, 68, 63-68.

Pant, G., Dhakal, M., Pradhan, N.M.B., Leverington, F. \& Hockings, M. (2016) Nature and extent of human-elephant Elephas maximus conflict in central Nepal. Oryx, 50, 724-731.

Peterson, M.N., Birckhead, J.L., Leong, K., Peterson, M.J. \& Peterson, T.R. (2010) Rearticulating the myth of human-wildlife conflict. Conservation Letters, 3, 74-82. 
R Core Team (2018) R: The R Project for Statistical Computing. Https://www.r-project.org/ [accessed 21 June 2018].

Redpath, S.M., Bhatia, S. \& Young, J. (2015) Tilting at wildlife: reconsidering human-wildlife conflict. Oryx, 49, 222-225.

Romañach, S.S., Lindsey, P.A. \& Woodroffe, R. (2007) Determinants of attitudes towards predators in central Kenya and suggestions for increasing tolerance in livestock dominated landscapes. Oryx, 41, 185-195.

Røskaft, E., Händel, B., BJerke, T. \& Kaltenborn, B.P. (2007) Human attitudes towards large carnivores in Norway. Wildlife Biology, 13, 172-185.

Saberwal, V.K., Gibbs, J.P., Chellam, R. \& Johnsingh, A.J.T. (1994) Lion-human conflict in the Gir Forest, India. Conservation Biology, 8, 501-507.

SARKer, A.H.M.R. \& Røskaft, E. (2011) Human attitudes towards the conservation of protected areas: a case study from four protected areas in Bangladesh. Oryx, 45, 391-40o.

Seidensticker, J. (2010) Saving wild tigers: a case study in biodiversity loss and challenges to be met for recovery beyond 2010 . Integrative Zoology, 5, 285-299.

Silwal, T., Kolejka, J., Bhatta, B.P., Rayamajhi, S., Sharma, R.P. \& Poudel, B.S. (2017) When, where and whom: assessing wildlife attacks on people in Chitwan National Park, Nepal. Oryx, 51, 370-377.

Smith, J.L.D., Ahearn, S.C. \& McDougal, C. (1998) Landscape analysis of tiger distribution and habitat quality in Nepal. Conservation Biology, 12, 1338-1346.

Sogbohossou, E.A., De Iongh, H.H., Sinsin, B., DE Snoo, G.R. \& Funston, P.J. (2011) Human-carnivore conflict around Pendjari Biosphere Reserve, northern Benin. Oryx, 45, 569-578.

Studsrød, J.E. \& Wegge, P. (1995) Park-people relationships: the case of damage caused by park animals around the Royal Bardia National Park, Nepal. Environmental Conservation, 22, 133-142.

TAMANG, B. \& BARAL, N. (2008) Livestock depredation by large cats in Bardia National Park, Nepal: implications for improving parkpeople relations. International Journal of Biodiversity Science and Management, 4, 44-53.

Thapa KARKI, S. (2013) Do protected areas and conservation incentives contribute to sustainable livelihoods? A case study of
Bardia National Park, Nepal. Journal of Environmental Management, 128, 988-999.

Treves, A. \& Karanth, K.U. (2003) Human-carnivore conflict and perspectives on carnivore management worldwide. Conservation Biology, 17, 1491-1499.

Treves, A., Wallace, R.B., Naughton-Treves, L. \& Morales, A. (2006) Co-managing human-wildlife conflicts: a review. Human Dimensions of Wildlife, 11, 383-396.

Tumenta, P.N., de Iongh, H.H., Funston, P.J. \& Udo de Haes, H.A. (2013) Livestock depredation and mitigation methods practised by resident and nomadic pastoralists around Waza National Park, Cameroon. Oryx, 47, 237-242.

Upadhyaya, S.K., Musters, C.J.M., Lamichhane, B.R., De Snoo, G.R., Thapa, P., Dhakal, M. et al. (2018) An insight into the diet and prey preference of tigers in Bardia National Park, Nepal. Tropical Conservation Science, 11, 194008291879947.

Van Bommel, L., Bij De Vaate, M. D., De Boer, W.F. \& De Iongh, H.H. (2007) Factors affecting livestock predation by lions in Cameroon. African Journal of Ecology, 45, 490-498.

Walston, J., Robinson, J.G., Bennett, E.L., Breitenmoser, U., DA FonseCA, G.A.B., Goodrich, J. et al. (2010) Bringing the tiger back from the brink-the six percent solution. PLOS Biology, 8, e1000485.

WANG, S.W. \& MACDONALD, D.W. (2006) Livestock predation by carnivores in Jigme Singye Wangchuck National Park, Bhutan. Biological Conservation, 129, 558-565.

Wegge, P., Odden, M., Pokharel, C.P. \& Storaas, T. (2009) Predator-prey relationships and responses of ungulates and their predators to the establishment of protected areas: a case study of tigers, leopards and their prey in Bardia National Park, Nepal. Biological Conservation, 142, 189-202.

Wegge, P., YadaV, S.K. \& Lamichinane, B.R. (2018) Are corridors good for tigers Panthera tigris but bad for people? An assessment of the Khata corridor in lowland Nepal. Oryx, 52, 35-45.

W oodroffe, R. \& Ginsberg, J.R. (1998) Edge effects and the extinction of populations inside protected areas. Science, 280, 2126-2128.

Woodroffe, R., Frank, L.G., Lindsey, P.A., Ole Ranah, S.M.K. \& ROMAÑACH, S. (2007) Livestock husbandry as a tool for carnivore conservation in Africa's community rangelands: a case-control study. Biodiversity and Conservation, 16, 1245-1260. 